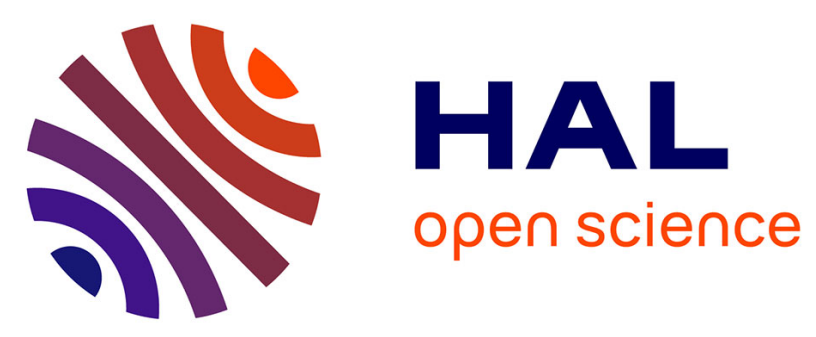

\title{
Improvement of FAO-56 method for olive orchards through sequential assimilation of thermal infrared-based estimates of ET
}

S. Er-Raki, Ghani Chehbouni, Joost Hoedjes, J. Ezzahar, Benoît Duchemin, Frédéric Jacob

\section{To cite this version:}

S. Er-Raki, Ghani Chehbouni, Joost Hoedjes, J. Ezzahar, Benoît Duchemin, et al.. Improvement of FAO-56 method for olive orchards through sequential assimilation of thermal infrared-based estimates of ET. Agricultural Water Management, 2008, 95 (3), pp.309-321. 10.1016/j.agwat.2007.10.013 . hal-02662341

\section{HAL Id: hal-02662341 \\ https://hal.inrae.fr/hal-02662341}

Submitted on 23 Jun 2021

HAL is a multi-disciplinary open access archive for the deposit and dissemination of scientific research documents, whether they are published or not. The documents may come from teaching and research institutions in France or abroad, or from public or private research centers.
L'archive ouverte pluridisciplinaire HAL, est destinée au dépôt et à la diffusion de documents scientifiques de niveau recherche, publiés ou non, émanant des établissements d'enseignement et de recherche français ou étrangers, des laboratoires publics ou privés. 


\title{
Improvement of FAO-56 method for olive orchards through sequential assimilation of thermal infrared-based estimates of ET
}

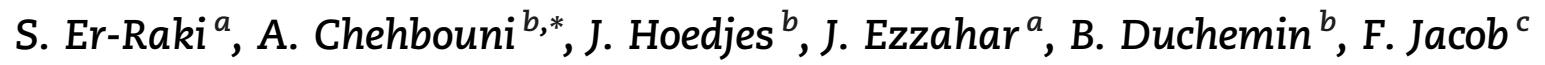

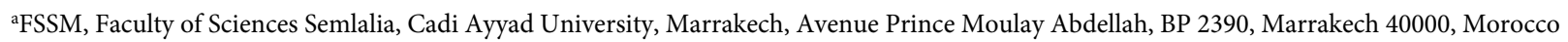 \\ ${ }^{b}$ Centre d'Etudes Spatiales de la Biosphère (CESBIO), 18 Avenue Edouard Belin, bpi 2801, 31401 Toulouse Cedex 9, France \\ 'IRD, Laboratoire d'études des Interactions Sols-Agrosystèmes-Hydrosystèmes,
}

\begin{abstract}
The aim of this study is to use the FAO-56-based single crop coefficient approach to estimate actual evapotranspiration (AET) of an olive (Olea europaea L.) orchard in the Mediterranean semi arid region of Tensift-basin (central Morocco) during two consecutive growing seasons (2003 and 2004). The results showed that using crop coefficients $K_{c}$ suggested by FAO-56 method yielded an AET overestimation by about $18 \%$ when compared against eddy covariance measurements. Therefore, the determination of appropriate $K_{c}$ values is required to accurately estimate crop water requirement of olive orchards in such water scarce area.

In this study, after applying the $K_{\mathrm{c}}$ values derived over olive orchard in Spain by Pastor and Orgaz [Pastor, M., Orgaz, F., 1994. Riego deficitario del olivar: los programas de recorte de riego en olivar. Agricultura 746, 768-776 (in Spanish)], a better agreement was observed between measured and simulated AET. The root mean square error (RMSE) was reduced by about $28 \%$, from 0.80 to $0.61 \mathrm{~mm} /$ day for 2003 and from 0.93 to $0.69 \mathrm{~mm} /$ day for 2004 . The used $K_{\mathrm{c}}$ values of olives at three crop growth stages (initial, mid-season and maturity) were $0.65,0.45$, and 0.65 , respectively, the mid-season stage value being considerably lower than that suggested by the FAO- 56 .

Despite these improvements in the performance of AET simulations, some discrepancies between measured and simulated AET remained, especially when water stress occurred. These discrepancies were ascribed to the estimation of the stress coefficient $K_{C}$ To overcome this problem, we assimilated into FAO-56 single source model estimates of AET derived from a simple energy balance model along with thermal infrared observations. The latter were collected with the ASTER sensor in 2003 and from ground-based measurements in 2004. The results showed a clear improvement for FAO-56 performances after assimilation: for 2003 and 2004, the RMSE values between observations and simulations, respectively, dropped down from 0.61 to 0.52 and from 0.69 to 0.46 (corresponding to relative reductions of 15 and $40 \%$, respectively).
\end{abstract}

\footnotetext{
* Corresponding author. Tel.: +33 5615585 23; fax: +33 561558500 .

E-mail address: ghani@cesbio.cnes.fr (A. Chehbouni).
} 


\section{Introduction}

Olive orchards are one of the most important crops in the semi arid Mediterranean regions, and cover about $8 \mathrm{Mha}$ in the world, of which $98 \%$ is located in the Mediterranean basin (Testi et al., 2004). With its Mediterranean climate, Morocco has good potential for olive production. Due to its high adaptability to semi-arid climate, olives make up the main component of the orchards in the Tensift Al Haouz basin (Marrakech, central of Morocco). In this region, olive yield depends on the water supply. The annual precipitation (about $240 \mathrm{~mm}$ /year) is not sufficient to fulfill crop water requirements under such climate. Irrigation is then necessary to prevent water stress and to ensure profitable yields.

Recent studies have shown that irrigation consumes more than $85 \%$ of the available water in arid and semi-arid regions (Chehbouni et al., 2007a). Therefore, the first step toward sound management of scarce water resources in these regions requires accurately estimating the spatio-temporal variability of water losses toward the atmosphere through evapotranspiration (ET). However, quantifying ET over large areas is not straightforward, since ET depends on several agronomic, biophysical, pedological as well as meteorological processes, such as atmospheric demand, water status of the soil surface and at the root zone.

The most common and practical approach used for estimating crop evapotranspiration is the FAO-56 method (Allen et al., 1998). This approach is often preferred due to its simplicity and its applicability at operational basis. It requires fewer inputs data, and provides acceptable ET estimates when compared to data hungry physically based models (Evett et al., 1995; Kite and Droogers, 2000; Eitzinger et al., 2002). Additionally FAO method can be used either with ground (e.g. Paço et al., 2006) or to satellite measurements (e.g. Allen, 2000; Kite and Droogers, 2000). In FAO-56 method, actual evapotranspiration (AET) is estimated using a reference evapotranspiration $\mathrm{ET}_{\mathrm{O}}$ which represents the atmospheric demand, a crop coefficient $K_{\mathrm{c}}$ which accounts for crop type and phenology, and a water stress coefficient $K_{\mathrm{s}}$ which explicit root zone and soil water status (Allen et al., 1998). This basic one source version, which includes a single crop coefficient, has been extended to a two source version. The latter includes dual crop coefficients: a transpiration-based basal crop coefficient $K_{\mathrm{cb}}$ and an evaporation coefficient $K_{\mathrm{e}}$, both adjusted for root zone and soil water status by using, respectively, water stress coefficient $K_{\mathrm{s}}$ and evaporation reduction coefficient $K_{\mathrm{r}}$.

When dealing with FAO-56 single crop coefficient, three parameters are required: reference evapotranspiration $\mathrm{ET}_{0}$, crop coefficient $K_{c}$ and water stress coefficient $K_{\mathrm{s}}$. ET $\mathrm{T}_{0}$ can be estimated using the FAO-Penman-Monteith equation which is recommended by the FAO as the standard method (Allen et al., 1998). The estimation of crop coefficient $K_{c}$ has been heavily investigated for different crops and under contrasted climate. Some investigations focused on olive orchards within Mediterranean regions, especially in southern Spain (Beede and Goldhamer, 1994; Pastor and Orgaz, 1994; Villalobos et al., 2000; Michelakis et al., 1994; Orgaz and Fereres, 1997; Testi et al., 2004). However, there is no simple way to calculate these crop coefficients, as they integrate several factors related to pedological, biophysical, physiological, and aerodynamic processes, most of them depending on agricultural practices (Katerji et al., 1991; Katerji and Rana, 2006; Testi et al., 2004). Estimating water stress coefficient $K_{\mathrm{s}}$ requires computing daily water balance for soil and root zone. However, this water balance includes several components which knowledge is not straightforward. This is the case for rooting depth (which directly influences root zone depletion), because of difficulties in measurements, especially when considering deciduous orchards with deep rooting systems (e.g. old olives, citrus, etc.).

In this context, remote sensing appears as a promising tool to overcome problems related to uncertainties on some parameters and variables. The use of remote sensing data along with FAO-56 has been mainly investigated by attempting to estimate crop coefficients $K_{c}$ from remotely sensed spectral reflectance (e.g. Jackson et al., 1980; Bausch and Neale, 1987; Neale et al., 1989; Choudhury et al., 1994; Hunsaker et al., 2003, 2005; Duchemin et al., 2006; Er-Raki et al., 2006, 2007). Some of these studies derived $K_{\mathrm{c}}$ or $\mathrm{K}_{\mathrm{cb}}$ from vegetation indices (VIs) such as normalized difference vegetation index (NDVI; Rouse et al., 1974) or soil adjusted vegetation index (SAVI; Huete, 1988), but they were restricted to estimating crop ET under standards conditions (i.e. absence of water stress). Less attention has been paid on determining water stress coefficient $K_{\mathrm{s}}$ from remote sensing data, because of difficulties in deriving the parameters used for calculating $K_{\mathrm{s}}$ Indeed, estimating soil and root zone moisture (or root zone depletion) from remote sensing data remains very challenging, especially for deciduous orchards characterized by deep rooting systems. A potential solution is the use of surface temperature derived from thermal infrared observations, since surface thermal and water status are intimately linked (Moran, 1994). Therefore the option of assimilating thermal infrared remote sensing data into FAO-56 method, as done with others models such as SVAT (Cayrol et al., 2000; Moulin et al., 2003; Verhoef and Bach, 2003; Boegh et al., 2004; Pellenq and Boulet, 2004; Merlin et al., 2006) seemed to be attractive.

This study aims at estimating AET over olive orchards in the semi arid region of Tensift $\mathrm{Al} \mathrm{Haouz,} \mathrm{by} \mathrm{applying} \mathrm{the} \mathrm{FAO-}$ 56 single crop coefficient approach. We first compare AET derived from FAO-56 to that measured with an eddy covariance device, by evaluating the necessity to reconsider crop coefficient. Next, we investigate the potential of assimilating AET estimates from thermal infrared data (satellite or ground based), to improve the performance of the FAO-56 approach. The main objectives of the study are:

1. Assessing the capability of the FAO-56 single crop coefficient approach, to provide accurate estimates AET over olive orchards in a semi-arid region.

2. Investigating the potential of assimilating AET derived from satellite thermal infrared observations, to improve the AET simulation performances from the FAO-56 single crop coefficient approach.

The paper is organized as follows. Section 2 describes the study site, the data collection during the 2003 and 2004 growing seasons, an overview of the FAO-56 single approach, and the assimilation procedure of thermal infrared observations into FAO-56 model. Section 3 reports and discusses the 
obtained results. We first present the application of FAO-56 over the olive orchard during 2003 and 2004 growing seasons, to estimate AET by using the standard $K_{c}$ values. We next reconsider appropriate $K_{c}$ coefficients for the olive orchards in such semi-arid region, by using coefficients proposed for similar land use and climatic conditions. We finally present the performances of FAO-56 when assimilating AET estimates derived from thermal infrared observations. The latter are obtained using advanced space borne thermal emission and reflection radiometer (ASTER) satellite data in 2003, and ground-based measurements in 2004. Finally, summary and conclusion are provided.

\section{Materials and methods}

\subsection{Data description}

\subsubsection{Experimental site}

The experiment was conducted within the Agdal olive (Olea europaea L.) orchard, located southeastern of Marrakech city, Morocco $(31.601 \mathrm{~N}, 7.974 \mathrm{~W})$. This area was characterized by a semi arid Mediterranean climate, with low and irregular rainfall (annual average of about $240 \mathrm{~mm}$ ). The experimental field included 240-year old olive trees, grown in an orchard of about 275 ha. The density of olive trees was about 225 trees/ha. The average height of the olive trees was about $6 \mathrm{~m}$; the soil surface was partly covered (15-20\%) by natural grass (under story), which mainly included short weeds during most of the year. Leaf area index (LAI) of the trees was measured using a LICOR 2000 plant canopy analyzer, and was equal to about $3 \mathrm{~m}^{2} / \mathrm{m}^{2}$. The orchard was periodically surface-irrigated through level basin flood irrigation, with water supplies of about $100 \mathrm{~mm}$ every each irrigation event (see Fig. 1). Each tree was bordered by a small earthen levy that retained irrigation water (Williams et al., 2004).

\subsubsection{Meteorological data and reference evapotranspiration}

Half-hourly measurements of classical climatic data were collected over olive trees using a standard micro meteorological weather station. Incoming solar radiation was measured at a $3.2 \mathrm{~m}$ above the canopy with a BF2 Delta T radiometer, air temperature and humidity were measured at $3.5 \mathrm{~m}$ height with Vaisala HMP45C probes, and wind speed was measured at a $9 \mathrm{~m}$ with A100R anemometers (R.M. Young Company, USA). The four net radiation components (incoming and outgoing shortwave and longwave) are measured with a Kipp and Zonen CNR1 net radiometer set up between the trees at $8.5 \mathrm{~m}$ height ( $2.5 \mathrm{~m}$ above canopy). It was installed in order to embrace same proportions of ground and canopy, and was oriented such as shadowing effects were minimized throughout the day. Radiative soil and vegetation temperatures were measured using 2 Infra Red Thermometers (IRTS-P's, Apogee), with a 3:1 field of view, at heights of $1 \mathrm{~m}$ and $8.4 \mathrm{~m}$, respectively. Soil heat flux was measured at a $1 \mathrm{~cm}$ depth using soil heat flux plates (Hukseflux). Three locations were selected such as measurements were spatially representative: one below the tree (always shaded), one between the trees (directly exposed to solar radiation) and one with an intermediate position. Rainfall was measured with a FSS500
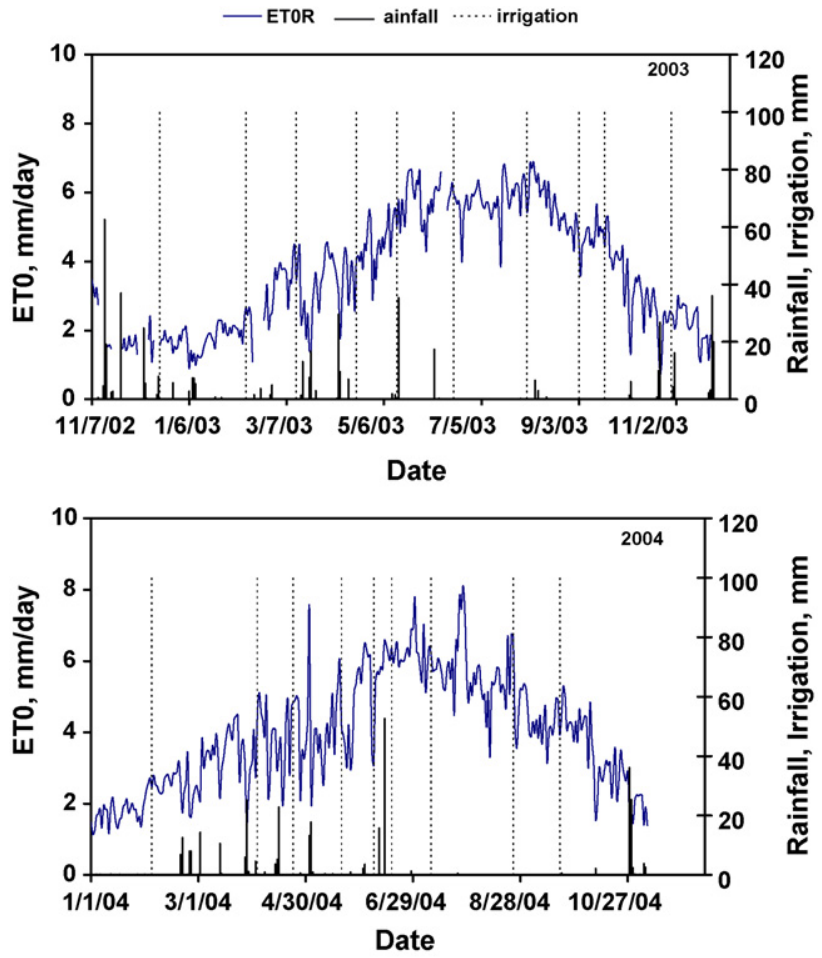

Fig. 1 - Daily reference evapotranspiration $\mathrm{ET}_{0}$ calculated following the FAO-Penman-Monteith equation during 2003 (top) and 2004 (bottom) growing seasons. Rainfall and irrigation events are shown in the same figures.

tipping bucket automatic rain gauge (Campbell Inc., USA). All meteorological measurements were sampled at $1 \mathrm{~Hz}$, averaged over $30 \mathrm{~min}$ and stored in a data logger (CR10, Campbell Scientific, USA).

Daily averaged values of climatic data were calculated in order to compute the daily reference evapotranspiration $\mathrm{ET}_{0}$ (mm/day), according to the following FAO-56 PenmanMonteith parameterization scheme:

$\mathrm{ET}_{0}=\frac{0.408 \Delta\left(R_{\mathrm{n}}-\mathrm{G}\right)+\gamma 900 / \mathrm{T}+273 u_{2}\left(e_{\mathrm{s}}-e_{\mathrm{a}}\right)}{\Delta+\gamma\left(1+0.34 u_{2}\right)}$

where $R_{n}$ is the net radiation at the crop surface $\left(M J /\left(m^{2}\right.\right.$ day)), $G$ is the soil heat flux density $\left(\mathrm{MJ} /\left(\mathrm{m}^{2}\right.\right.$ day)), $\mathrm{T}$ is the air temperature at $2 \mathrm{~m}$ height $\left({ }^{\circ} \mathrm{C}\right), \mathrm{u}_{2}$ is the wind speed at $2 \mathrm{~m}$ height $(\mathrm{m} / \mathrm{s}), e_{\mathrm{s}}$ is the saturation vapor pressure $(\mathrm{kPa}), e_{\mathrm{a}}$ is the actual vapor pressure, $\Delta$ is the slope of the vapor pressure curve $(\mathrm{kPa} /$ ${ }^{\circ} \mathrm{C}$ ) and $\gamma$ is the psychrometric constant $\left(\mathrm{kPa} /{ }^{\circ} \mathrm{C}\right)$. A logarithmic wind speed profile (Eq. (47) in FAO-56) was used to adjust wind speed data from elevation measurements $(9 \mathrm{~m})$ to the standard height recommended by FAO-56 (2 m).

By considering daily averaged values, $G$ was assumed to be negligible following Allen et al. (1998), and $e_{\mathrm{s}}$ was computed as: $e_{\mathrm{s}}=e^{0}\left(\mathrm{~T}_{\max }\right)+e^{0}\left(\mathrm{~T}_{\min }\right) / 2$, where $e^{0}()$ is the saturation vapor function and $T_{\max }$ and $T_{\min }$ are the daily maximum and minimum air temperature, respectively. Standardized equations for computing all parameters in Eq. (1) are given in Allen et al. (1998). Note that the measurements of meteorological data were not taken over the grass, which is considered to be 
the reference surface for computing $\mathrm{ET}_{0}$ (Allen et al., 1998, 2005).

Fig. 1 shows the seasonal variations, within the olive orchard during the 2003 and 2004 growing seasons, for the reference evapotranspiration $\mathrm{ET}_{0}$ calculated from Eq. (1). The $\mathrm{ET}_{\mathrm{O}}$ temporal pattern is typically that of a semi-arid continental climate. It is characterized by a high climatic demand, with an accumulated $\mathrm{ET}_{0}$ value of about $1150 \mathrm{~mm}$ between March and November (the growing season of olive trees). The lowest $\mathrm{ET}_{0}$ values occurred during rainy periods (winter), and the highest ones occurred during sunny days (summer). Precipitation temporal patterns over the growing season of olive trees were characterized by low and irregular rainfall events, with a total precipitation amount of about $280 \mathrm{~mm}$ (Fig. 1). By considering a $K_{\mathrm{c}}$ value proposed by the FAO-56 paper for an olive orchard with a $60 \%$ ground cover, the simple comparison of precipitation amount against yearly integrated value of $\mathrm{K}_{\mathrm{c}} \times \mathrm{ET}_{0}=786 \mathrm{~mm}$ indicates the inevitability to irrigate olives trees with a integrated water supply of at least $506 \mathrm{~mm}$ during the growing season.

\subsubsection{Eddy-covariance measurements}

An eddy-covariance (EC) system was installed over the olive trees to provide continuous measurements of vertical fluxes of heat $\left(H_{\mathrm{EC}}\right)$ and water vapor $\left(L_{\mathrm{V}} H_{\mathrm{EC}}\right)$ at a $9.2 \mathrm{~m}$ height. The EC system consisted of commercially available instrumentations: a 3D sonic anemometer (CSAT3, Campbell Scientific Ltd.), which measured the fluctuations of both temperature and wind velocity components, and an open-path infrared gas analyzer (Li7500, Licor Inc.), which measured concentration of water vapor. Raw data were sampled at a rate of $20 \mathrm{~Hz}$ and were recorded using CR23X data loggers (Campbell Scientific Ltd.). The half-hourly values of fluxes were later calculated offline after performing coordinate rotation, correcting the sonic temperature for the lateral velocity and the humidity effects, making frequency integration, and including the mean vertical velocity according to Webb et al. (1980), Schotanus et al. (1983) and Wilczak et al. (2001).

The performance of flux measurements was assessed by the energy balance closure. By neglecting the term of canopy heat storage and the radiative energy used in photosynthesis (Testi et al., 2004; Baldocchi et al., 2000), the energy balance equation is given by $R_{n}-G=H_{E C}+L_{v} E_{E C}$, where $R_{n}$ is the net radiation, $G$ is the soil heat flux, and $H_{\mathrm{EC}}$ and $L_{\mathrm{V}} E_{\mathrm{EC}}$ are, respectively, sensible heat flux and latent heat flux measured by eddy covariance system. The comparison between the daily available energy from $\left(R_{n}-G\right)$ and from $\left(H_{E C}+L_{v} E_{E C}\right)$, showed an underestimation of the flux $\left(H_{\mathrm{EC}}+L_{\mathrm{V}} E_{\mathrm{EC}}\right)$ by about $10 \%$ during 2003 and 8\% during 2004 (data not shown here). To correct this non-closure of energy balance, we adopted the approach suggested by Twine et al. (2000). This method assumes the Bowen ratio $\left(H_{\mathrm{EC}} / \mathrm{L}_{\mathrm{V}} \mathrm{E}_{\mathrm{EC}}\right)$ can be measured correctly, and the energy balance non-closure results from errors in the eddy covariance measurements. Based on this assumption, we recalculated sensible and latent heat fluxes by forcing the energy balance closure using the measured available energy $\left(R_{n}-G\right)$ and Bowen ratio.

The source area (Fetch) for the turbulent fluxes, which corresponds to the contributing surface patches to scalar flux measurements from the eddy covariance device, was calcu- lated using the analytical footprint model proposed by Horst and Weil (1992, 1994). Fetch was about $40 \mathrm{~m}$ in the northwestern direction (Hoedjes et al., 2007a). It might be considered adequate as it contributed by $90 \%$ to the measured surface convective fluxes. The analysis of the footprint model showed the resolution of ASTER thermal imagery $(90 \mathrm{~m})$ covers the source area dimensions for a typical eddycovariance set-up (Hoedjes, 2007; Hoedjes et al., 2007b). Finally, the resulting dataset of sensible and latent heat fluxes were available for the 2003 and 2004 growing seasons, with missing data for few days due to power supply troubles.

\subsection{An overview of the FAO-56 single approach}

In this section, only a brief summary of the FAO-56 model is provided. The reader can refer to Allen et al. (1998) and Pereira et al. (1999) for detailed descriptions. The FAO-56 approach has been designed and extensively used to derive crop evapotranspiration and to schedule irrigation on an operational basis. FAO-56 is based on the concepts of reference evapotranspiration $\mathrm{ET}_{0}$ and crop coefficients $K_{\mathrm{c}}$, which have been introduced to separate the climatic demand from the plant response under standard conditions (e.g. no water stress). For actual estimates of crop evapotranspiration (AET), $K_{c}$ is adjusted by the water stress coefficient $K_{\mathrm{s}}$ which explicits hydric status:

$\mathrm{AET}=\mathrm{K}_{\mathrm{S}} \mathrm{K}_{\mathrm{C}} \mathrm{ET}_{0}$

Additionally to $\mathrm{K}_{\mathrm{C}}$, two parameters are necessary to determine $(\mathrm{AET}): K_{\mathrm{c}}$ and $K_{\mathrm{S}}$. Deriving both are presented hereafter.

\subsubsection{Calculation of $\mathrm{K}_{\mathrm{C}}$}

In the FAO-56 procedure, the $K_{c}$ curves are divided into four growth stage periods: the initial $\left(l_{\text {ini }}\right)$, the development $\left(l_{\mathrm{dev}}\right)$, the midseason $\left(l_{\mathrm{mid}}\right)$ and the late season $\left(l_{\text {late }}\right)$. The initial and midseason periods are characterized by horizontal line segments, the development and late season periods are characterized by rising and falling line segments, respectively. Thus three critical $K_{c}$ values are required to generate the entire $K_{\mathrm{c}}$ curve, namely the $K_{\mathrm{c}}$ during the initial period, $K_{\text {cini, }}$, the $K_{\mathrm{C}}$ during the midseason, $K_{\mathrm{cmid}}$, and the $K_{\mathrm{c}}$ at the end of the growth season, $K_{\text {cend. }}$ In the Mediterranean regions such as in Morocco, the olive season lasts from the 1st of March through to the 25th of November, and the lengths of crop development stages $\left(l_{\text {ini }}, l_{\text {dev }}, l_{\text {mid }}\right.$ and $\left.l_{\text {late }}\right)$ are, respectively, 30, 90, 60 and 90 days (Allen et al., 1998). The remaining period (from December to February) of the year was called "off season stage".

As mentioned in Section 2.1.1, two different crops (olive and under story) grew up together in the same field. A simple formula was used to calculate the equivalent crop coefficient (Allen et al., 1998):

$K_{\text {c field }}=f_{\text {c-olives }} K_{\text {c ngc }}+\left(1-f_{\text {c-olives }}\right) K_{\text {c cover }}$

where $K_{\mathrm{c} \text { ngc }}$ and $K_{\mathrm{c} \text { cover }}$ are crop coefficients for olive and under story, respectively. $f_{c-o l i v e s}$ is the fraction cover of olive trees, calculated as $f_{\text {c-olives }}=\left(\pi D^{2} N / 40,000\right)$, where $D(m)$ is the average diameter of the canopy and $N$ is the number of trees per hectare. Fraction cover of olive trees was found to be equal to 0.60 . 


\subsubsection{Derivation of $K_{\mathrm{s}}$}

The effect of soil water stress on crop AET is taken into account by multiplying the crop coefficient by the water stress coefficient $K_{\mathrm{S}}$. The latter is a dimensionless factor which depends on available soil and root zone water, and which ranges between 0 and 1 .

$\mathrm{K}_{\mathrm{s}}$ is equal to unity (no water stress) when readily available water RAW is larger than the root zone depletion $\left(D_{\mathrm{r}}\right)$. RAW is expressed from the total available water in the root zone TAW $(\mathrm{mm})$ as

$\mathrm{RAW}=p \mathrm{TAW}$

where $p$ is the fraction of TAW that vegetation can extract from the root zone without suffering from water stress. TAW is estimated as the difference between water content at field capacity $\theta_{\mathrm{fc}}$ and wilting point $\theta_{\mathrm{wp}}\left(Z_{\mathrm{r}}\right.$ is the effective rooting depth, $\mathrm{m})$ :

$\mathrm{TAW}=1000\left(\theta_{\mathrm{fc}}-\theta_{\mathrm{wp}}\right) Z_{\mathrm{r}}$

Water stress occurs when $D_{\mathrm{r}}$ is larger than RAW. Then, $K_{\mathrm{s}}$ is given by

$K_{\mathrm{S}}=\frac{\mathrm{TAW}-D_{\mathrm{r}}}{\mathrm{TAW}-\mathrm{RAW}}=\frac{\mathrm{TAW}-\mathrm{D}_{\mathrm{r}}}{(1-p) \mathrm{TAW}}$

Water depletion $D_{r}$ is calculated using a water budget within the root zone. The simple daily water balance, expressed in terms of root zone depletion at the end of day $i$ is

$D_{\mathrm{r}, \mathrm{i}}=\mathrm{D}_{\mathrm{r}, \mathrm{i}-1}-\mathrm{I}_{\mathrm{i}}-\mathrm{P}_{\mathrm{i}}+\mathrm{AET}_{\mathrm{i}}$

where $D_{r, i}$ and $D_{r, i-1}$ are the root zone depletion at the end of day $i$ and at the end of the previous day, $i-1$, respectively $(\mathrm{mm}), P_{i}$ is the precipitation on day $i(\mathrm{~mm}), I_{i}$ is the irrigation depth on day $i(\mathrm{~mm}), \mathrm{AET}_{i}$ is the actual evapotranspiration at day $i(\mathrm{~mm})$, calculated by Eq. (2).

In Eq. (7), the water loss by deep percolation was neglected. In fact, Doorenbos and Pruitt (1977) and Allen et al. (1998) reported depletion $D_{r}$ is positive and percolation is negligible if root zone soil moisture is lower than soil moisture at field capacity. This is the case in our study where soil moisture is always lower than that at field capacity $\left(0.32 \mathrm{~m}^{3} / \mathrm{m}^{3}\right)$.

From the equations listed above, the required soil parameters are $\theta_{\mathrm{fc}}, \theta_{\mathrm{wp}}$ and $Z_{\mathrm{r}}$ (Eq. (5)). For the considered soil type (silt clay loam), Allen et al. (1998) indicated soil moisture at field capacity $\theta_{\mathrm{fc}}$ ranges between 0.3 and $0.37 \mathrm{~m}^{3} / \mathrm{m}^{3}$, and soil moisture at wilting point $\theta_{\mathrm{wp}}$ ranges between 0.17 and $0.24 \mathrm{~m}^{3} /$ $\mathrm{m}^{3}$. To estimate $\theta_{\mathrm{fc}}$ and $\theta_{\mathrm{wp}}$, Wosten (1997) and Wosten et al. (1999) expressed pedotransfer functions from soil texture, by using the model of Van Genutchen (1980). The values of $\theta_{\mathrm{fc}}$ obtained by the models of Wosten (1997) and Wosten et al. (1999) were 0.32 and $0.27 \mathrm{~m}^{3} / \mathrm{m}^{3}$, respectively. The values of $\theta_{\mathrm{wp}}$ obtained by these two models were 0.19 and $0.14 \mathrm{~m}^{3} / \mathrm{m}^{3}$, respectively. A cross comparison showed the values of $\theta_{\mathrm{fc}}$ and $\theta_{\text {wp }}$ obtained by Wosten (1997) model are in accordance with those reported by Allen et al. (1998) for silt clay loamy soil (Table 19 in FAO-56). Based on these considerations, average values of $0.32 \mathrm{~m}^{3} / \mathrm{m}^{3}$ for $\theta_{\mathrm{fc}}$ and $0.19 \mathrm{~m}^{3} / \mathrm{m}^{3}$ for $\theta_{\mathrm{wp}}$ were selected for our study. The rooting depth $Z_{\mathrm{r}}$ of olive trees and the depletion fraction $p$ were set at $1.60 \mathrm{~m}$ and 0.65 , respectively, following FAO-56 values (Table 22 in FAO-56). RAW and TAW were calculated from Eqs. (4) and (5), and were equal to 135.2 and $208 \mathrm{~mm}$, respectively.

In what follows, the FAO-56 single approach described above was firstly applied to estimate AET of olive orchard with recommended $K_{\mathrm{c}}$ in the FAO-56 tables (case 1, see Section 3.1), and after by using the coefficients proposed by Pastor and Orgaz (1994) for olive orchards in Spain with similar climatic conditions (case 2, see Section 3.2). The performance of FAO-56 AET simulations was finally improved by assimilating thermal infrared observations into FAO-56 method. The data assimilation procedure is described hereafter.

\subsection{Data assimilation procedure}

As mentioned above, two parameters were necessary to estimate (AET) by the FAO-56 single approach (Eq. (2)): $K_{\mathrm{C}}$ and $K_{\mathrm{s}}$. The values of $K_{\mathrm{c}}$ could be calculated using Eq. (3), as explained in Section 2.2.1. The calculation of $K_{\mathrm{s}}$ from Eq. (6) depended on $Z_{\mathrm{r}}, p$ and $D_{\mathrm{r}}$. $Z_{\mathrm{r}}$ and $p$ were directly taken from Table 22 in FAO-56. $D_{r}$ was derived from the root zone water balance (Eq. (7)). Uncertainties on these three variables yielded to error on $K_{s}$ values. Correcting these errors could be performed by using ground-based measurements of root zone moisture. However, accurately obtaining root zone soil moisture at different space-time scales is not really feasible at operational basis. In this regard, as stated in the introduction, the use thermal infrared observations might provide a workable solution for improving the monitoring of water consumption on an operational basis. Consequently, $K_{\mathrm{s}}$ was corrected by assimilating AET derived from ASTER data during 2003 and ground-based measurements during 2004. AET assimilation allowed updating $D_{\mathrm{r}}$ (Eq. (7)), and therefore controlling the temporal dynamic of the root zone water budget (explained further in Section 3.3), from which the water stress coefficient was derived. The assimilation procedure used here was that proposed by Schuurmans et al. (2003):

$\mathrm{AET}_{\text {new }}=\mathrm{AET}_{\text {old }}+\left(\frac{\sigma_{\mathrm{AET}}^{2}}{\sigma_{\mathrm{AET}}^{2}+\sigma_{\text {Aster }}^{2}}\right) \times\left(\mathrm{AET}_{\text {Thermal }}-\mathrm{AET}_{\text {old }}\right)$

This simple sequential assimilation scheme is preferred due to its simplicity and thus its applicability for operational purposes. Contrary, other assimilation methods like variational scheme requires more complicated mathematical calculus (adjunct model, stochastic simulations, etc.).

The Eq. (8) can be rewritten as following:

$\mathrm{AET}_{\text {new }}=\mathrm{AET}_{\text {old }}+\mathrm{K} \times\left(\mathrm{AET}_{\text {Thermal }}-\mathrm{AET}_{\text {old }}\right)$

where $\mathrm{AET}_{\text {old }}$ and $\mathrm{AET}_{\text {new }}$ are AET estimated by the FAO-56 single approach before and after data assimilation, respectively. $\mathrm{AET}_{\text {Thermal }}$ is that derived from thermal infrared observations (ASTER data or ground-based measurements). $\sigma_{\mathrm{AET}}^{2}$ and $\sigma_{\text {Thermal }}^{2}$ are the variances of predicted errors on AET estimates from FAO-56 model and thermal infrared observations, respectively (see the appendix for the calculation of $\sigma^{2}$ ). The difference $\left(\mathrm{AET}_{\text {Thermal }}-\mathrm{AET}_{\text {old }}\right)$ is called innovation that reflects the discrepancy between uncorrected and observed 
AET. $K$ is the Kalman gain that minimizes the analyzed error covariance and is equal to

$\mathrm{K}=\frac{\sigma_{\mathrm{AET}}^{2}}{\sigma_{\mathrm{AET}}^{2}+\sigma_{\text {Thermal }}^{2}}$

This algorithm was applied to assimilate AET derived from both ASTER data (2003) and ground-based observations (2004). Six ASTER images were collected during 2002-2003 growing season of olive orchards: one in 2002 (November 7), and 5 in 2003 (February 27, May 18, July 21, October 9 and October 16). For consistency when assimilating ground-based measurements, we performed a sensitivity analysis to identify the most relevant time frequency to achieve accurate estimates of AET through assimilation (see Section 3.3).

Thermal infrared-based AET was derived using the surface energy balance model proposed by Lhomme et al. (1994), which required micrometeorological measurements (Section 2.1), net radiation, soil heat flux and surface radiative temperature. Net radiation and soil heat flux were derived from ASTER visible-near infrared-thermal infrared data in 2003 (see the following next paragraph), and from ground-based measurements in 2004. Surface radiative temperature was derived from ASTER thermal infrared data in 2003, and from ground-based measurements in 2004. Further, the AET instantaneous estimates at satellite overpass were extrapolated to the daily scale using the approach proposed by Hoedjes (2007), Hoedjes et al. (2007b). Both Lhomme's model and Hoedjes's approach are presented hereafter.

\subsubsection{Estimating daily AET}

Latent heat flux (LE) was derived as the residual term of the energy balance equation:

$L E=R_{n}-G-H$

$R_{n}$ is net radiation calculated as a function of albedo $(\alpha)$, surface emissivity $(\varepsilon)$ and radiometric temperature $T_{S}$, incoming short wave $\left(S^{\downarrow}\right)$ and long wave $\left(L^{\downarrow}\right)$ radiation:

$R_{\mathrm{n}}=(1-\alpha) \mathrm{S}^{\downarrow}+\varepsilon\left(\mathrm{L}^{\downarrow}-\sigma \mathrm{T}_{\mathrm{s}}^{4}\right)$

where $\sigma$ is Stephan-Boltzmann's constant. Deriving $\mathrm{T}_{\mathrm{s}}, \alpha$ and $\varepsilon$ from ASTER data were performed using ASTER official products from EDC gateway server: AST_07 visible-near infrared reflectance, AST_05 spectral thermal infrared emissivities, and AST_08 radiometric temperature (see detailed description in Hoedjes, 2007; Hoedjes et al., 2007b). Albedo was calculated as a linear combination of visible and near infrared reflectance following Jacob et al. (2002), and the emissivity was derived from ASTER thermal infrared emissivities following Ogawa et al. (2003).

$G$ is soil heat flux calculated as the function of $R_{n}$ according to Santanello and Friedl (2003) model:

$\frac{G}{R_{n}}=A \cos \left[\frac{2 \pi(t+10,800)}{B}\right]$

where $A$ and $B$ are empirical coefficients equal to 0.31 and $74000 \mathrm{~s}$, respectively.
$\mathrm{H}$ is sensible heat flux, calculated using the semi-empirical model proposed by Lhomme et al. (1994):

$H=\rho C_{p}\left[\frac{\left(T_{\mathrm{s}}-\mathrm{T}_{\mathrm{a}}\right)-c \delta \mathrm{T}}{r_{\mathrm{a}}-r_{\mathrm{e}}}\right]$

where $C_{p}$ is the specific heat of air at constant pressure $\left(\mathrm{J} \mathrm{kg}^{-1} \mathrm{~K}^{-1}\right), \rho$ is the air density $\left(\mathrm{kg} \mathrm{m}^{-3}\right), \mathrm{T}_{\mathrm{a}}$ is the air temperature at reference height $(\mathrm{K}), \mathrm{T}_{\mathrm{s}}$ is the surface temperature derived from ASTER images in 2002-2003 season and from ground measurements in 2004 and $r_{\mathrm{a}}\left(\mathrm{s} \mathrm{m}^{-1}\right)$ is the aerodynamic resistance to heat transfer between the canopy source and the reference height. $r_{\mathrm{a}}$ is calculated using the classical equation which takes into account the stability correction functions for wind and temperature (Brutsaert, 1982).

The equivalent resistance, $r_{\mathrm{e}}\left(\mathrm{s} \mathrm{m}^{-1}\right)$, is given by

$r_{\mathrm{e}}=\frac{r_{\mathrm{af}} r_{\mathrm{as}}}{r_{\mathrm{af}}+r_{\mathrm{as}}}$

where $r_{\text {as }}$ and $r_{\text {af }}$ are, respectively, the aerodynamic resistance between the soil and the canopy source height (Shuttleworth and Gurney, 1990), and the canopy bulk boundary layer resistance (Choudhury and Monteith, 1988).

The term $c \delta \mathrm{T}(\mathrm{K})$, is given by

$c \delta \mathrm{T}=\left(\left[\frac{1}{1+\left(r_{\mathrm{af}} / r_{\mathrm{as}}\right)}\right]-f\right) a\left(\mathrm{~T}_{\mathrm{s}}-\mathrm{T}_{\mathrm{a}}\right)^{m}$

where $f$ is the cover fraction, $a$ and $m$ are empirical coefficients equal to 0.25 and 2 , respectively.

The method described above calculates instantaneous evapotranspiration (LE) estimates only. Extrapolating LE into daily estimates, which is the main interest for agricultural water management, has been investigated by many studies (e.g. Jackson et al., 1977, 1983; Sugita and Brutsaert, 1991; Zhang and Lemeur, 1995; Gomez et al., 2005). Some of those studies linked midday instantaneous surface air temperature differences to daily total evapotranspiration. Others developed techniques based on similarity between the diurnal course of evapotranspiration and that of solar radiation. A third way is using evaporative fraction (EF) to convert the instantaneous evapotranspiration obtained into daily value. In the current study, LE instantaneous estimates were extrapolated to daily value using the method developed by Hoedjes (2007), Hoedjes et al. (2007b). The latter was based on the parameterization of diurnal behavior of EF from atmospheric parameters and soil moisture status (dry or wet). As reported by Hoedjes (2007), Hoedjes et al. (2007b) and Chehbouni et al. (2007b), an increase of EF is mainly due to an increase of incoming solar radiation and a decrease of atmospheric humidity. Therefore, EF could be adjusted with incoming solar radiation $\left(S^{\downarrow}\right)$ and relative humidity $(\mathrm{RH})$ :

$\mathrm{EF}_{\text {sim }}=\mathrm{A}-\left(\mathrm{B} \frac{\mathrm{S}^{\downarrow}}{1000}+\mathrm{C} \frac{\mathrm{RH}}{100}\right)$

where $A, B$ and $C$ are empirical coefficients equal to 1.2, 0.4 and 0.5 , respectively. Those coefficients were derived by Hoedjes (2007), Hoedjes et al. (2007b) over the same study site. 
In order to account of the effect of soil moisture on EF, Hoedjes (2007), Hoedjes et al. (2007b) adjusted $\mathrm{EF}_{\text {sim }}$ by a correction factor $r_{\mathrm{EF}}^{1130}$ :

$\mathrm{EF}_{\text {sim }}^{\mathrm{ACT}}= \begin{cases}\mathrm{EF}_{\text {sim }} r_{\mathrm{EF}}^{1130} & \text { for } \beta^{1130} \leq 1.5 \\ \mathrm{EF}_{\mathrm{Obs}}^{1130} & \text { for } \beta^{1130}>1.5\end{cases}$

where $r_{\mathrm{EF}}^{1130}$ sets the parameterized $\mathrm{EF}$ at the local time of thermal infrared observations (ASTER overpass at 1130 UTC and ground-based data selection) to the actual EF at 1130 UTC:

$r_{\mathrm{EF}}^{1130}=\frac{\mathrm{EF}_{\mathrm{Obs}}^{1130}}{\mathrm{EF}_{\mathrm{sim}}^{1130}}$

The 1.5 value in Eq. (18) is the threshold value of Bowen ratio $\beta$ that gives satisfactory results for the estimation of $E F$. $\mathrm{EF}_{\mathrm{Obs}}^{1130}$ is the derived EF from thermal infrared observations (ASTER data or ground-based measurements).

Daily actual evapotranspiration AET can then be calculated by the following equation:

$\mathrm{AET}=\mathrm{EF}_{\mathrm{sim}}^{\mathrm{ACT}}\left(R_{\mathrm{n}}-\mathrm{G}\right)$

The calculation of AET requires the diurnal course of Available Energy $A E=R_{n}-G$. Here again, the similar heuristic approach developed by Hoedjes (2007), Hoedjes et al. (2007b) was applied to derive the AE diurnal course. The daytime variation of $\mathrm{AE}$ was formulated as

$\frac{\left(R_{n}-G\right)^{t}}{\left(R_{n}-G\right)_{\text {Obs }}^{1130}}=f\left(\frac{R^{* t}}{R^{* 1130}}\right)$

where $R^{*}$ is the net radiation calculated from Eq. (12). $f$ is the polynomial second-order function given by

$f\left(\frac{R^{* t}}{R^{* 1130}}\right)=a_{0}+a_{1}\left(\frac{R^{* t}}{R^{* 1130}}\right)+a_{2}\left(\frac{R^{* t}}{R^{* 1130}}\right)^{2}$

where $a_{0}, a_{1}$ and $a_{2}$ are empirical coefficients given by Hoedjes (2007), Hoedjes et al. (2007b) as $-0.48495,1.15120$ and 0.34285, respectively.

The performance of this model to estimate AET was heavily discussed in Hoedjes (2007), Hoedjes et al. (2007b). They reported that the use of the proposed model improves significantly the simulated AET over the same site and using the same data set. The Root Mean Square Error (RMSE) between measured and simulated AET was $18 \mathrm{~W} \mathrm{~m}^{-2}$. Knowing the complexity of the site, this result can be considered as very satisfactory. Additionally, this same approach has been extended with success to heterogeneous surfaces (Chehbouni et al., 2007b).

\section{Results and discussions}

\subsection{Estimating AET by the FAO-56 single approach}

The temporal course of AET using the FAO-56-based single crop coefficient approach over olive trees has been first simulated considering standard $K_{c}$ values given in FAO-56
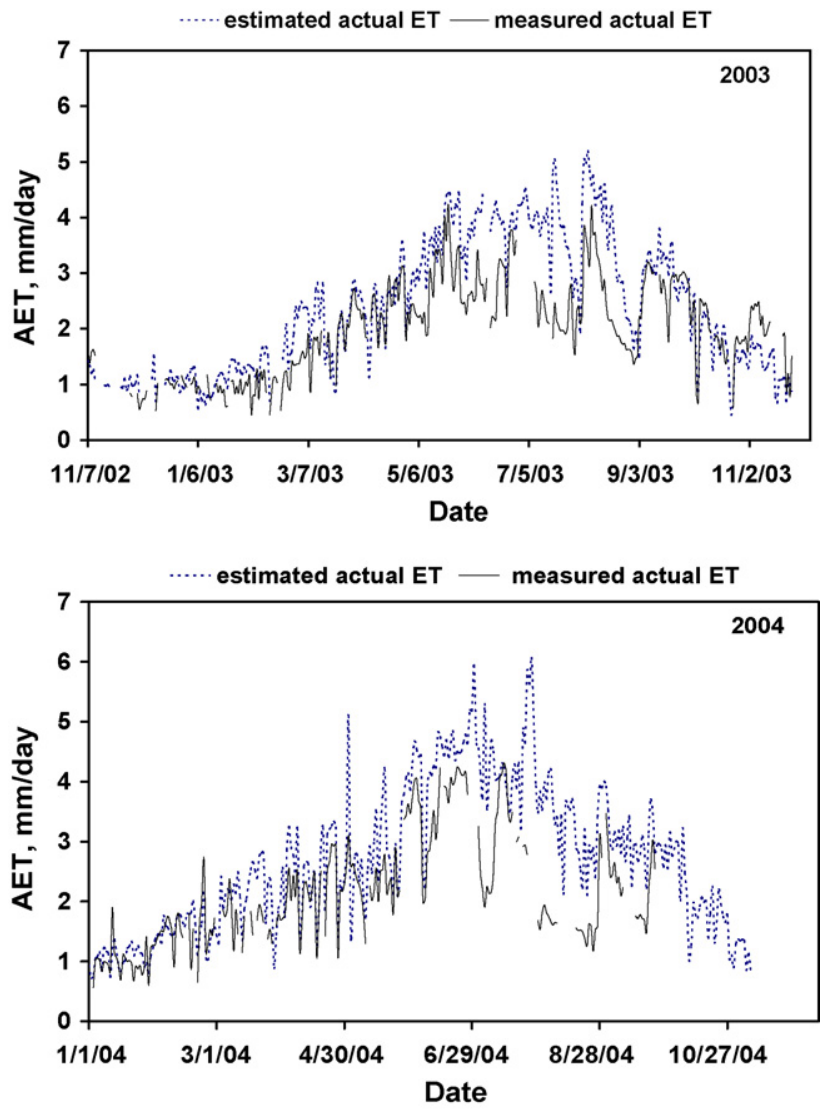

Fig. 2 - Time course of observed (solid line) and simulated (dotted line) actual evapotranspiration (AET) for 2003 (top) and 2004 (bottom) growing seasons of olives orchard, using the FAO-56 single crop coefficient approach along with the crop coefficient suggested by Allen et al. (1998).

tables 12 (Allen et al., 1998). The simulation was performed from 7 November 2002 to 25 November 2003 for the 2003 growing season, and from 1 March to 7 November for the 2004 growing season.

Fig. 2 shows the temporal courses of measured (from eddy covariance system) and simulated (from single crop coefficient approach) AET, for the 2003 (top) and 2004 (bottom) growing seasons. The FAO-56 single crop coefficient approach gave acceptable results over the two growing seasons. The statistical results are presented in Table 1 (equations used to calculate the statistical parameters are summarized in Appendix A). The root mean square error (RMSE) between measured and simulated AET values during 2003 and 2004 was, respectively, 0.80 and $0.93 \mathrm{~mm} /$ day. It could be seen the model tended to overestimate AET by about $16 \%$ and $20 \%$ during 2003 and 2004, respectively. The explanation of this overestimation was twofold. First, the values of $K_{c}$ were not appropriate. Second, water stress coefficient $K_{\mathrm{s}}$ was poorly estimated using the very simplistic FAO-56 water balance (Eq. (6)). This resulted in larger AET values as compared to measurements, because of misrepresenting rooting depth which directly influenced the plant ability for water uptake.

According to these results, it can be stated that it is possible to use the FAO-56 single approach along with the standard $\mathrm{K}_{\mathrm{c}}$ 
Table 1 - Statistical analysis of actual evapotranspiration (AET) simulated by the FAO-56 single crop coefficient approach with three methods ( $K_{c}$ suggested by Allen et al. (1998), Pastor and Orgaz (1994) and after the data assimilation) of olives orchards during 2003 and 2004 growing season

\begin{tabular}{|c|c|c|c|c|c|c|}
\hline \multirow[t]{3}{*}{ Method } & \multicolumn{6}{|c|}{ Statistical parameters } \\
\hline & \multicolumn{2}{|c|}{ RMSE (mm/day) } & \multicolumn{2}{|c|}{$\operatorname{MBE}(\mathrm{mm} /$ day $)$} & \multicolumn{2}{|c|}{$E$} \\
\hline & 2003 & 2004 & 2003 & 2004 & 2003 & 2004 \\
\hline Allen et al. (1998) & 0.80 & 0.93 & 0.39 & 0.53 & 0.04 & 0.06 \\
\hline Pastor and Orgaz (1994) & 0.61 & 0.69 & 0.15 & 0.22 & 0.44 & 0.48 \\
\hline After assimilation $^{\mathrm{a}}$ & 0.52 & 0.46 & -0.14 & -0.06 & 0.59 & 0.76 \\
\hline
\end{tabular}

Note: RMSE, root mean square error ( $\mathrm{mm} /$ day); $\mathrm{MBE}$, mean bias error ( $\mathrm{mm} /$ day); $E$, efficiency.

${ }^{a}$ The assimilation was made by the AET derived from ASTER thermal infrared during 2003, and from ground thermal infrared during 2004.

values suggested by Allen et al. (1998), to derive estimates of water consumption of olive orchards in the Tensift $\mathrm{Al} \mathrm{Haouz}$ semi-arid region, with somehow acceptable accuracy. However, knowing the shortage, cost of dam water in the region, or that of energy requirements for water extraction from groundwater, any improvement would be very useful. Therefore, a better estimation of $K_{c}$ and $K_{s}$ was needed to accurately estimate the crop water requirements of olive orchards and thus to optimize the use of this scarce resource.

\subsection{Deriving appropriate crop coefficient $K_{c}$}

Several studies showed the coefficient is highly correlated with ground cover for different crops (e.g. Heilman et al., 1982; Ritchie and Johnson, 1990; de Medeiros et al., 2001; Williams and Ayars, 2005). In the case of olive orchards within Spain, Pastor and Orgaz (1994) found $K_{\mathrm{c} \mathrm{ini}}=0.65, K_{\mathrm{c} \text { mid }}=0.45$ and $K_{\mathrm{c} \text { end }}=0.65$ for a $60 \%$ ground cover olive orchard irrigated by flooding technique. Villalobos et al. (2000) found annual $K_{c}$ values around 0.62 and 0.55 for olive trees with 30 and $40 \%$ ground cover, respectively. Recently, Testi et al. (2004) proposed a simple linear relationship between olive ground cover and $\mathrm{K}_{\mathrm{c}}$. They obtained $K_{\mathrm{c}}$ values for olive young trees of about 0.15 for $5 \%$ ground cover, and 0.3 for $25 \%$. Based on these findings and since the ground cover was about $60 \%$ for the olive orchard considered in this study, $\mathrm{K}_{\mathrm{c}}$ values proposed by Pastor and Orgaz (1994) were selected for the current study. For the off season (low phenological activity) period (from December to February), a $0.50 \mathrm{~K}_{\mathrm{c}}$ value was used, following Allen et al. (1998).

The comparison between measured and simulated AET (Fig. 3) shows good agreement between both during 2003 (top) and 2004 (bottom) seasons. The Efficiency (E) between measured and simulated AET values for 2003 and 2004 were, respectively, 0.44 and 0.48 when using the $K_{c}$ values suggested by Pastor and Orgaz (1994); while they were 0.04 and 0.06 when using those suggested by Allen et al. (1998). The additional statistical results presented in Table 1 confirmed this clear improvement. However, some discrepancies between measured and simulated AET still remained. Despite the adjustment of $K_{c}$ value, the FAO-56 model overestimated eddy covariance measurements during 2003, from 27 February to 16 March and from 7 July to 2 August. A similar behavior occurred during 2004, from 30 July to 23 August. This could result from an overestimation of water stress, since the latter was poorly computed from a very simplistic water balance and/or a misrepresentation of the soil stress factor. To overcome the problem associated with the calculation of stress coefficient $K_{\mathrm{s}}$, we next assimilated thermal infrared-based AET (Eq. (8)) to update the temporal course of root zone depletion. This allowed controlling the root zone water budget, and then correcting the resulting stress coefficient $K_{\mathrm{s}}$.

\subsection{Assimilating thermal infrared observations into FAO- 56 model}

Before applying the data assimilation procedure described above during the entire 2003 and 2004 seasons, we first
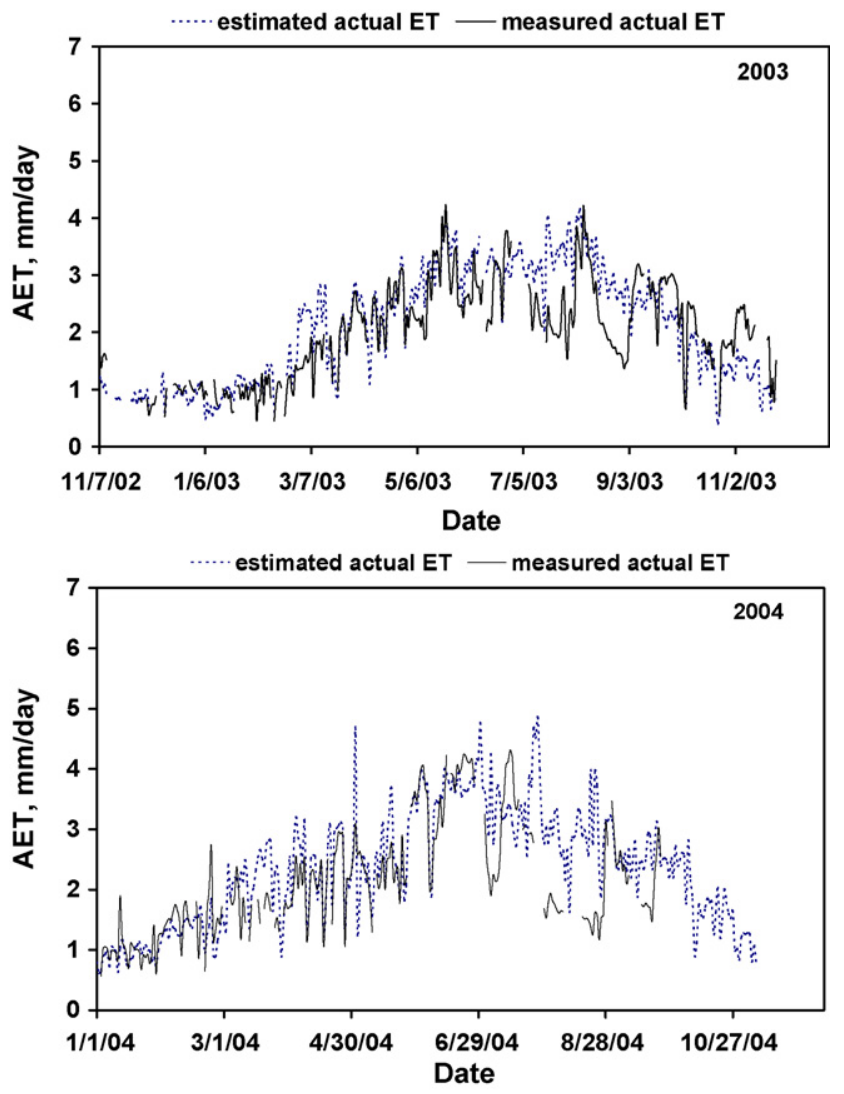

Fig. 3 - Time course of observed (solid line) and simulated (dotted line) actual evapotranspiration (AET) for 2003 (top) and 2004 (bottom) growing seasons of olives orchard, using the FAO-56 single crop coefficient approach along with the crop coefficient suggested by Pastor and Orgaz (1994). 

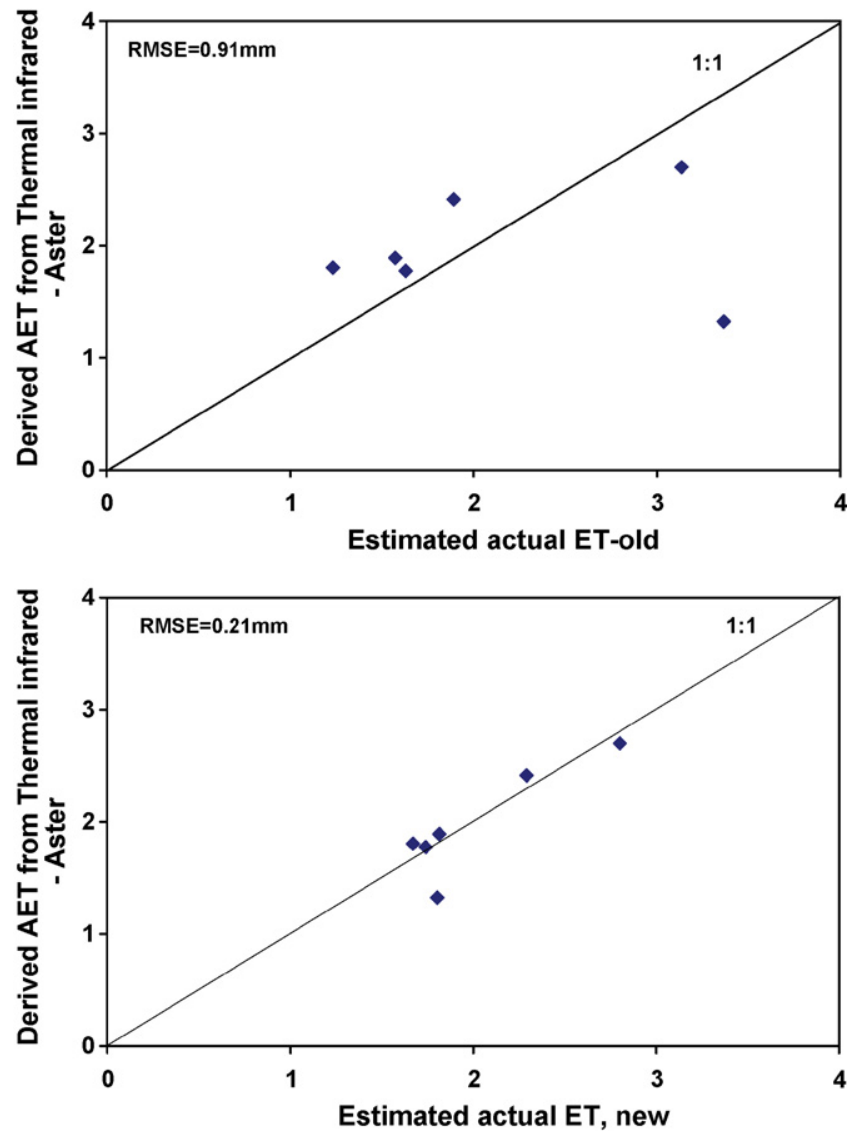

Fig. 4 - Scatter plot between AET derived from thermal infrared of ASTER (6 days) and that estimated by FAO model before assimilation (Fig. 5 (top)) and after assimilation (Fig. 5 (bottom)) during 2003 season.

compared for 2003 the AET estimates derived from ASTER (6 days) and those estimated by FAO-56 model without assimilation (Fig. 4-top) and with assimilation (Fig. 4-bottom). As shown by Fig. 4, there is a clear improvement in the estimation of AET by FAO- 56 with assimilation: RMSE values between AET derived from ASTER and that estimated by FAO model dropped down from 0.91 to $0.21 \mathrm{~mm} /$ day. After this comparison, we assimilated the thermal infrared-based AET derived from ASTER during 2003 and ground-based thermal data during 2004. This allowed updating the root zone depletion $D_{r}$, and thus controlling the temporal course of root zone water budget, which lead to correcting the $K_{\mathrm{S}}$ values. Fig. 5 displays the comparison between the estimated $K_{\mathrm{s}}$ by FAO-56 model with and without assimilation during 2003 and 2004 growing seasons. It can be seen that $K_{\mathrm{s}}$ ranged from 0 to 1 according to Eq. (6). The $K_{s}$ value depended on soil water depletion, which was linked to water supply (rainfall or irrigation). The water stress coefficient was equal to 1 when root zone depletion was lower than RAW, and it dropped below 1 otherwise. $K_{\mathrm{s}}$ was supposed to be lower than 1 when the water supplies were lacking (particularly between 18 June and 2 August during 2003, and between 9 July and 24 August during 2004) and for large $\mathrm{ET}_{0}$ values. However, no stress was observed during these periods before assimilation (Fig. 5). This confirmed the
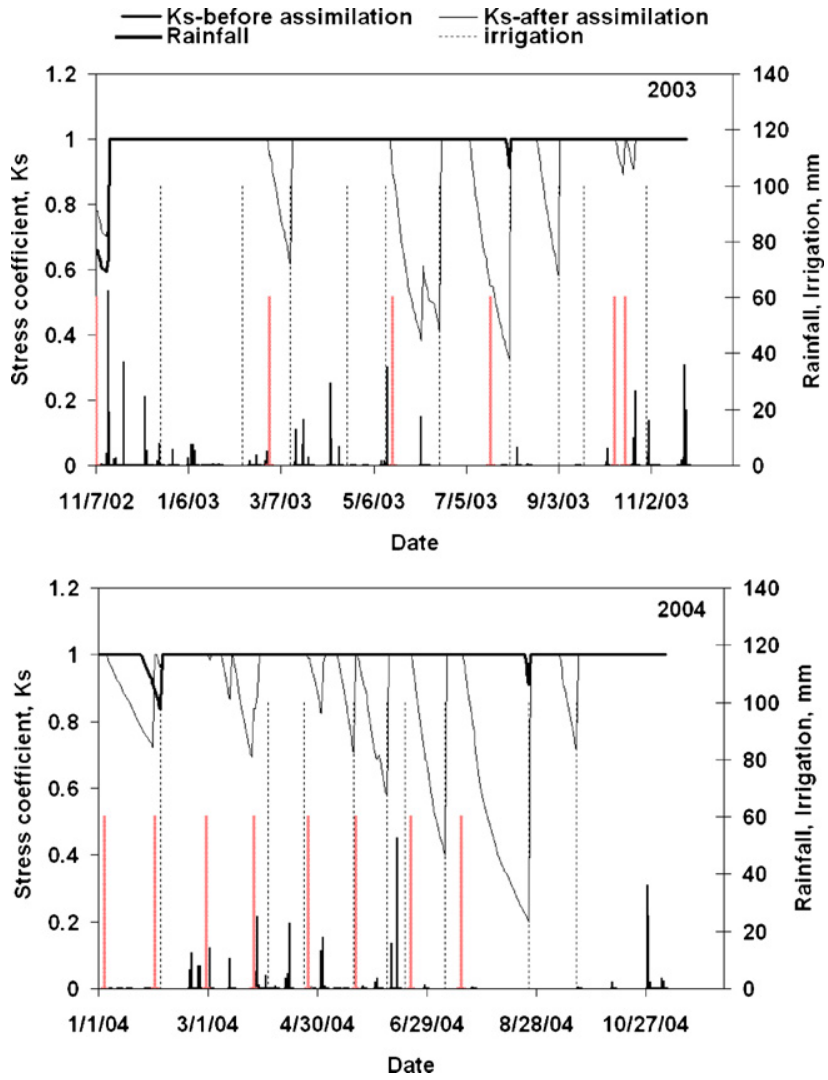

Fig. 5 - Comparison between the stress coefficient $K_{\mathrm{s}}$ calculated by the FAO-56 model before assimilation (bold solid line) and the updated one after assimilation (solid line) during 2003 and 2004. Rainfall and irrigation events are shown in the same figures. Vertical red bars indicate the assimilation dates.

fact that some parameters (especially the rooting depth $Z_{\mathrm{r}}$ and/ or the depletion fraction $p$ ) were not appropriate, leading to an overestimation of $K_{s}$. Once thermal infrared-based AET was assimilated, the updated values of $K_{s}$ (Fig. 5) correctly responded to water supply (rainfall or irrigation). This can be clearly seen from 7 July to 2 August during 2003, and from 22 July to 24 August during 2004 when $K_{\mathrm{s}}$ was below 1 while it was equal to 1 before assimilation.

Fig. 6 (top) shows the temporal course of observed and simulated AET during 2003 after assimilation. Along with Table 1, it is shown assimilation improved the estimation of AET by FAO model. The Efficiency (E) between measured and simulated AET values for 2003 was about 0.59 with data assimilation while it was 0.44 without data assimilation. Despite this substantial improvement, some discrepancies between measured and simulated AET occurred especially after the third and fourth assimilation dates during 2003 (see Fig. 6 (top)). This might result either from errors in the remote sensing derived variables (e.g. albedo, emissivity, surface temperature), or from the energy balance model, both yielding errors in AET estimation (Hoedjes, 2007; Hoedjes et al., 2007b).

Regarding 2004 growing season, the assimilation was based on AET derived from ground-based thermal infrared. Acquiring high resolution clear sky satellite thermal infrared data 
Table 2 - Statistics associated to sensitivity analysis for the assimilation data into FAO-56 model during 2004 for each frequency $(F)$ : every week, every 2 weeks, every 4 weeks, every 8 weeks and every 12 weeks

\begin{tabular}{lccccc} 
Statistical parameters & $F=1$ week & $F=2$ weeks & $F=4$ weeks & $F=8$ weeks & $F=12$ weeks \\
\hline RMSE & 0.52 & 0.50 & 0.46 & 0.50 & 0.54 \\
MBE & 0.12 & 0.05 & -0.06 & 0.04 & 0.09 \\
E & 0.71 & 0.72 & 0.76 & 0.73 & 0.69 \\
\hline
\end{tabular}

once a month is more likely that once a week. Therefore, we selected dates corresponding to a 4-week frequency for assimilation. Fig. 6 (bottom) shows the temporal course of observed and simulated AET during 2004 after data assimilation. As shown in Table 1, the estimated AET by FAO model was clearly improved after assimilation. The efficiency $(E)$ between measured and simulated AET values was about 0.76 with data assimilation while it was 0.48 without data assimilation. The additional statistical results presented in
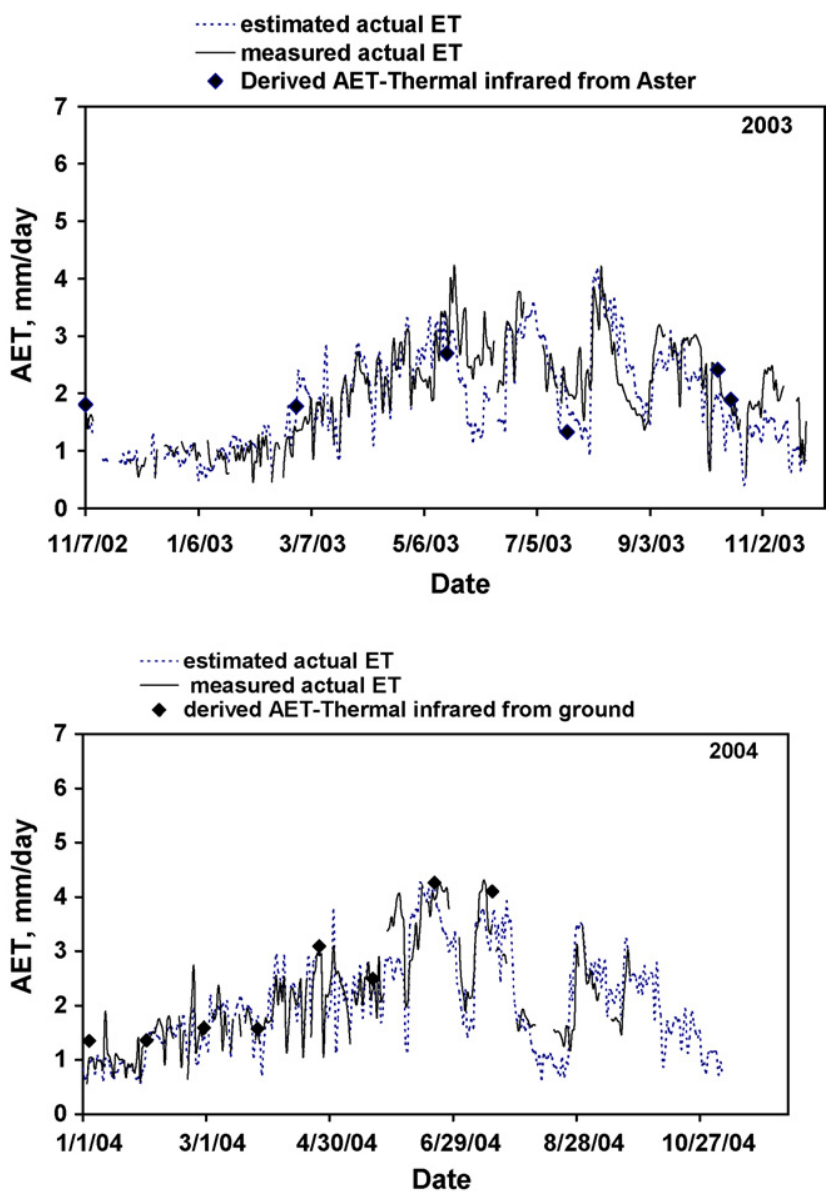

Fig. 6 - Comparison between observed (solid line) and simulated (dotted line) actual evapotranspiration (AET) using the FAO-56 single crop coefficient approach for 2003 (top) and 2004 (bottom) growing seasons of olives orchard, after data assimilation. The values of AET (lozenge) derived from thermal infrared of ASTER during 2003 and from thermal infrared of ground during 2004, and used for the assimilation procedure are presented in the same figures. Missing some data of the measurements of surface temperature leads to the missing AET for assimilation.
Table 1 confirm this clear improvement in the simulation of AET after assimilation.

Since we were not limited in terms of availability for ground-based thermal data, it was of interest investigating the optimal number of assimilation dates to achieve accurate estimates of AET. For this purpose, we considered five possibilities of assimilation frequencies: every week, every 2 weeks, every 4 weeks, every 8 weeks and every 12 weeks. Some of these possibilities corresponded to various satellite revisit time frequencies (e.g. ASTER, MODIS, LANDSAT, etc.) and others could be considered as an academic exercise.

The AET estimated by the FAO-56 single approach after data assimilation for each frequency $(F)$ was compared to field observations. The evaluation was based on statistical analysis which was applied for each frequency (F) (Table 2). According to the statistics displayed in this table, it appeared at a first glance the seasonal AET was well reproduced for the 4 week frequency: the RMSE $(0.46 \mathrm{~mm})$ was much lower for this frequency than for the other ones, especially for 1 and 2 weeks. This is somewhat surprising since one may expect the higher the assimilation frequency, the better the results are. However, a detailed examination showed the selected dates for this 4-week frequency corresponded to the dates with the largest differences between measured and FAO simulated AET. It can also be seen in Table 2 that the performance of AET after assimilation for the low frequency (e.g. 12 weeks) is much lower which is somehow expected.

\section{Conclusions}

The main results of this study showed that using standard crop coefficients suggested by FAO-56 paper, the FAO-56 model provides an acceptable estimate of AET of the olive orchard in this semi-arid region. However, the model tended to overestimate measured AET by about $18 \%$ when compared to eddy covariance measurements. Therefore, the determination of the appropriate $K_{c}$ values was needed to estimate more accurately the crop water requirement and consumption for olive orchards under semi-arid conditions of Morocco.

After using $\mathrm{K}_{\mathrm{c}}$ values devoted to Spanish olive orchards (Pastor and Orgaz, 1994), a clear improvement was observed, with a better correspondence between measured and simulated AET. The root mean square error (RMSE) was reduced from 0.80 to $0.61 \mathrm{~mm} /$ day for 2003 and from 0.93 to $0.69 \mathrm{~mm}$ / day for 2004 . The $K_{c}$ values of olive trees at three crop growth stages (initial, mid-season and maturity) were $0.65,0.45$, and 0.65 , respectively. These values were lower than those suggested by the FAO-56, by about $15 \%$.

Despite such improvement in the performances of FAO-56 AET simulations, some differences between measured and 
estimated AET appear under stress conditions. This is due to problems associated with uncertainties in some key hydric parameters. In particular, the rooting depth which directly influences the stress coefficient $K_{\mathrm{s}}$ remains a challenging topic because of the difficulties in measurement, especially for deciduous orchards (e.g. olives, citrus, etc.). To overcome this limitation associated to the calculation of stress coefficient $K_{\mathrm{s}}$, we assimilated, into the FAO-56 soil water budget, daily AET derived through the combination of thermal data (remotely sensed and ground based), energy balance model and extrapolations of instantaneous AET to daily values. The results showed a clear improvement of FAO-56 performances when constrained with thermal infrared-based AET. The RMSE between measured and simulated AET values for 2003 and 2004 were, respectively, about 0.52 and 0.46 with data assimilation while they were 0.61 and 0.69 without data assimilation. Finally, it should be noted that the procedure proposed here, i.e. assimilating thermal infrared-based observations into FAO-56 model, have been solely tested over a single irrigated olive orchard. Testing this procedure with other data set is needed before drawing any firm conclusions. Nevertheless, it appears that combining remote sensed data in both solar and thermal domains with the FAO-56 model provides a promising avenue for better management of irrigation water since the two sources of errors, i.e. $K_{\mathrm{c}}$ and $K_{\mathrm{s}}$ values can be removed, at least partial, through this combination.

\section{Acknowledgements}

This study was supported by SUDMED (IRD-UCAM), PAI ('Programme d'Action Intégrée du Comité Mixte Interuniversitaire Franco-Marocain, "Volubilis" 06/148") and the IRRIMED ('Improved management tools for water-limited irrigation: combining ground and satellite information through models', see http://www.irrimed.org/, as well as PLEADeS see http:// www.pleiades.es/ projects funded by the European Union (7th PCRD). The authors thank the director and staff of the Agdal olive orchard for access and use of the field site and for assistance with irrigation scheduling and security. We also thank three anonymous reviewers for their instructive comments.

\section{Appendix A. Statistical analysis}

Four statistics were used for analyzing the data: (1) the mean bias error (MBE), which indicates the average deviation of the predicted values from the measured values; (2) the root mean square error (RMSE), which measures the discrepancy of predicted values around observed values; (3) the efficiency (E), which judges the performances of simulation data; (4) the variance $\left(\sigma^{2}\right)$ to predict the error on AET.

$\mathrm{MBE}=\bar{y}_{\mathrm{mod}}-\bar{y}_{\mathrm{obs}}$

$\operatorname{RMSE}=\sqrt{\frac{1}{n} \sum_{i=1}^{n}\left(y_{i \text { mod }}-y_{i \text { obs }}\right)^{2}}$
$E=1-\frac{\sum_{i=1}^{n}\left(y_{i \text { mod }}-y_{i o b s}\right)^{2}}{\sum_{i=1}^{n}\left(y_{i o b s}-\bar{y}_{\text {obs }}\right)^{2}}$

$\sigma^{2}=\frac{1}{n-1} \sum_{i=1}^{n}\left(y_{\text {imod }}-\bar{y}_{\text {mod }}\right)^{2}$

where $\bar{y}_{\text {mod }}$ and $\bar{y}_{\text {obs }}$ are the averages of simulations and observations, $n$ is the number of available observations, $y_{i \text { mod }}$ and $y_{i}$ obs are daily values of modeled and observed variables, respectively.

\section{REFERENCES}

Allen, R.G., Pereira, L.S., Raes, D., Smith, M., 1998. Crop Evapotranspiration-Guidelines for Computing Crop Water Requirements, Irrigation and Drain, Paper No. 56. FAO, Rome, Italy, $300 \mathrm{pp}$.

Allen, R.G., 2000. Using the FAO-56 dual crop coefficient method over an irrigated region as part of an evapotranspiration intercomparison study. J. Hydrol. 229, 27-41.

Allen, R.G., Pruitt, W.O., Wright, J.L., Howell, T.A., Ventura, F., Snyder, R., Itenfisu, D., Steduto, P., Berengena, J., Yrisarry, J.B., Smith, M., Pereira, L.S., Raes, D., Perrier, A., Alves, I., Walter, I., Elliott, R., 2005. A recommendation on standardized surface resistance for hourly calculation of reference $\mathrm{ET}_{0}$ by the FAO56 Penman-Monteith method. Agric. Water Manage. 81, 1-22.

Baldocchi, D.D., Law, B.E., Anthoni, P.M., 2000. On measuring and modeling energy fluxes above the floor of a homogeneous and heterogeneous conifer forest. Agric. For. Meteorol. 102, 187-206.

Bausch, W.C., Neale, C.M.U., 1987. Crop coefficients derived from reflected canopy radiation: a concept. Trans. ASAE 30 (3), 703-709.

Beede, R.H., Goldhamer, D.A., 1994. Olive irrigation management. In: Ferguson, L., Sibbett, G.S., Martin, G.C. (Eds.), Olive Production Manual, vol. 3353. University of California Publication, pp. 61-68.

Boegh, E., Thorsen, M., Butts, M.B., Hansena, S., Christiansen, J.S., Abrahamsen, P., Hasager, C.B., Jensen, N.O., Van der Keur, P., Refsgaard, J.C., Schelde, K., Soegaard, H., Thomsen, A., 2004. Incorporating remote sensing data in physically based distributed agro-hydrological modelling. J. Hydrol. 287 (1-4), 279-299.

Brutsaert, W., 1982. Evaporation into the Atmosphere. Reidel, Dordrecht, $299 \mathrm{pp}$.

Cayrol, P., Moulin, S., Kergoat, L., Dedieu, G., Chehbouni, A., 2000. Calibrating a coupled SVAT/vegetation growth model with remotely sensed reflectance and surface temperature. A case study for the HAPEX-Sahel grassland sites. J. Appl. Meteorol. 39, 2452-2472.

Chehbouni, A., Escadafal, R., Boulet, G., Duchemin, B., Simonneaux, V., Dedieu, G., Mougenot, B., Khabba, S., Kharrou, H., Merlin, O., Chaponnière, A., Ezzahar, J., Er-Raki, S., Hoedjes, J., Hadria, R., Abourida, H., Cheggour, A., Raibi, F., Hanich, L., Guemouria, N., Chehbouni, Ah., Olioso, A., Jacob, F., Sobrino, J., 2007a. The use of remotely sensed data for integrated hydrological modeling in arid and semi-arid regions: the SUDMED program. Int. J. Remote Sens., in press.

Chehbouni A., Hoedjes, J.C.B., Rodriquez, J.-C., Watts, C.J., Garatuza, J., Jacob, F., Kerr, Y.H., 2007b. Using remotely sensed data to estimate area-averaged daily surface fluxes over a semi-arid mixed agricultural land. Agric. For. Meteorol., in press. 
Choudhury, B.J., Monteith, J.L., 1988. A four-layer model for the heat budget of homogeneous land surfaces. Quart. J. R. Meteorol. Soc. 114, 373-398.

Choudhury, B.J., Ahmed, N.U., Idso, S.B., Reginato, R.J., Daughtry, C.S.T., 1994. Relations between evaporation coefficients and vegetation indices studies by model simulations. Remote Sens. Environ. 50, 1-17.

de Medeiros, G.A., Arruda, F.B., Sakai, E., Fujiwars, M., 2001. The influence of crop canopy on evapotranspiration and crop coefficient of beans (Phaseolus vulgaris L.). Agric. Water Manage. 49, 211-224.

Doorenbos, J., Pruitt, W.O., 1977. Crop water requirements. Food and Agriculture Organization of the United Nations. FAO Irrigation and Drainage Paper No. 24, Rome, 144 pp. (revised).

Duchemin, B., Hadria, R., Er-Raki, S., Boulet, G., Maisongrande, P., Chehbouni, A., Escadafal, R., Ezzahar, J., Hoedjes, J., Karroui, H., Khabba, S., Mougenot, B., Olioso, A., Rodriguez, J.-C., Simonneaux, V., 2006. Monitoring wheat phenology and irrigation in Central Morocco: on the use of relationship between evapotranspiration, crops coefficients, leaf area index and remotely-sensed vegetation indices. Agric. Water Manage. 79, 1-27.

Eitzinger J., Marinkovic D., Hösch J., 2002. Sensitivity of different evapotranspiration calculation methods in different cropweather models. In: Rizzoli, A.E., Jakeman, A.J. (Eds.), Integrated Assessment and Decision Support. Proceedings of the First Biennial Meeting of the International Environmental Modelling and Software Society (IEMSS), vol. 1, June 24-27, 2002, Lugano, Switzerland, pp. 395-400.

Er-Raki, S., Chehbouni, A., Guemouria, N., Duchemin, B., Ezzahar, J., Hadria, R., BenHadj, I., 2006. Driven FAO-56 dual crop coefficient approach with remotely-sensed data for estimating water consumptions of wheat crops in a semiarid region. In: Proceedings of the Second International Symposium on Recent Advances in Quantitative Remote Sensing, RAQRS'II, Valencia, Spain, September 25-29, 2006.

Er-Raki, S., Chehbouni, G., Guemouria, N., Duchemin, B., Ezzahar, J., Hadria, R., 2007. Combining FAO-56 model and ground-based remote sensing to estimate water consumptions of wheat crops in a semi-arid region. Agric. Water Manage. J. 87, 41-54.

Evett, S.R., Howell T.A., Schneider A.D., Tolk J.A., 1995. Crop coefficient based evapotranspiration estimates compared with mechanistic model results. In: Espey, W.H., Combs, P.G. (Eds.), Water Resources Engineering, vol. 2. Proceedings of the First International Conference, August 14-18, 1995, San Antonio, TX, USA.

Gomez, M., Sobrino, J., Olioso, A., Jacob, F., 2005. Retrieval of evapotranspiration over the Alpilles test site using PolDER and thermal camera data. Remote Sens. Environ. 96, 399-408.

Heilman, J.L., Heilman, W.E., Moore, D.G., 1982. Evaluating the crop coefficient using spectrales reflectance. Agron. J. 74, 967-971.

Hoedjes, J., 2007. Estimation de l'Evapotranspiration sur des Surfaces Irriguées en Zones Semi-arides: Combinaison Modélisation, Télédétection et Scintillométrie. Université Paul Sabatier (UPS) Toulouse, France, Thèse en Météorologie, Hydrologie et Télédétection, p. 167.

Hoedjes, J.C.B., Chehbouni, A., Ezzahar, J., Escadafal, R., De Bruin, H.A.R., 2007a. Comparison of large aperture scintillometer and eddy covariance measurements: can thermal infrared data be used to capture footprint induced differences? J. Hydrometeorol. 8 (2), 144-159.

Hoedjes, J.C.B., Chehbouni, A., Jacob, F., Ezzahar, J., Boulet, G., 2007b. Can instantaneous evaporative fraction estimated from remote sensing be used to derive day-time evapotranspiration over irrigated olive orchards in semiarid regions? J. Hydrol. (submitted for publication).

Horst, T.W., Weil, J.C., 1992. Footprint estimation for scalar flux measurements in the atmospheric surface layer. Bound.Layer Meteorol. 59, 279-296.

Horst, T.W., Weil, J.C., 1994. How far is far enough? The fetch requirements for micrometeorological measurement of surface fluxes. J. Atmos. Oceanic Technol. 11, 1018-1025.

Huete, A.R., 1988. A soil-adjusted vegetation index (SAVI). Remote Sens. Environ. 25, 295-309.

Hunsaker, D.J., Pinter Jr., P.J., Barnes, E.M., Kimball, B.A., 2003. Estimating cotton evapotranspiration crop coefficients with a multispectral vegetation index. Irrig. Sci. 22, 95-104.

Hunsaker, D.J., Pinter Jr., P.J., Kimball, B.A., 2005. Wheat basal crop coefficients determined by normalized difference vegetation index. Irrig. Sci. 24, 1-14.

Jackson, R.D., Reginato, R.J., Idso, S.B., 1977. Wheat canopy temperature: a practical tool for evaluating water requirements. Water Resour. Res. 13, 651-656.

Jackson, R.D., Idso, S.B., Reginato, R.J., Pinter Jr., P.J., 1980. Remotely sensed crop temperatures and reflectances as inputs to irrigation scheduling. In: Irrigation and Drainage Special Conference Proceedings, Boise, Idaho, ASCE, New York, July 23-25, pp. 390-397.

Jackson, R.D., Hatfield, J.L., Reginato, R.J., Idso, S.B., Pinter Jr., P.J., 1983. Estimation of daily evapotranspiration from one timeof-day measurements. Agric. Water Manage. 7, 351-362.

Jacob, F., Weiss, M., Olioso, A., French, A., 2002. Assessing the narrowband to broadband conversion to estimate visible, near infrared and shortwave apparent albedo from airborne PolDER data. Agron.: Agric. Environ. 22, 537-546.

Katerji, N., Hamdy, A., Raad, A., Mastrorilli, M., 1991. Conséquence d'une contrainte hydrique appliquée à différents stades phénologiques sur le rendement des plantes de poivron. Agronomie 11, 679-687.

Katerji, N., Rana, G., 2006. Modelling evapotranspiration of six irrigated crops under Mediterranean climate conditions. Agric. For. Meteorol. 138, 142-155.

Kite, G.W., Droogers, P., 2000. Comparing evapotranspiration estimates from satellites, hydrological models and field data. J. Hydrol. 209, 3-18.

Lhomme, J.-P., Monteny, B., Chehbouni, A., Troufleau, D., 1994. Determination of sensible heat flux over Sahelian fallow savannah using infra-red thermometry. Agric. For. Meteor. 68, 93-105.

Merlin, O., Chehbouni, A.G., Boulet, G., Kerr, Y., 2006. Assimilation of the disaggregated microwave soil moisture into hydrological modeling using coarse resolution meteorological data: a study case based on the Monsoon '90 data. J. Hydrometeorol. 7 (6), 1308-1322.

Michelakis, N.I.C., Vouyoucalou, E., Clapaki, G., 1994. Soil moisture depletion, evapotranspiration and crop coefficients for olive trees cv. kalamon, for different levels of soil water potential and methods of irrigation. Acta Hort. 356, 162-167.

Moran, M.S., 1994. Irrigation management in Arizona using satellites and air planes. Irrig. Sci. 15, 35-44.

Moulin, S., Kergoat, L., Cayrol, P., Dedieu, G., Prévot, L., 2003. Calibration of a coupled canopy functioning and SVAT model in the ReSeDA experiment: towards the assimilation of SPOT/HRV observations into the model. Agronomie 22, 681-686.

Neale, C.M.U., Bausch, W.C., Heerman, D.F., 1989. Development of reflectance-based crop coefficients for corn. Trans. ASAE 32 (6), 1891-1899.

Ogawa, K., Schmugge, T., Jacob, F., French, A., 2003. Estimation of land surface window (8-12 $\mathrm{mm}$ ) emissivity from multispectral thermal infrared remote sensing - a case study in a part of Sahara Desert. Geophys. Res. Lett. 30, 1067-1071. 
Orgaz, F., Fereres, E., 1997. Riego. In: Barranco, D., FernandezEscobar, R., Rallo, L. (Eds.), El cultivo del olivo. MundiPrensa, Madrid, pp. 251-272.

Paço, T.A., Ferreira, M.I., Conceiçao, N., 2006. Peach orchard evapotranspiration in a sandy soil: comparison between eddy covariance measurements and estimates by the FAO 56 approach. Agric. Water Manage. 85, 305-313.

Pastor, M., Orgaz, F., 1994. Riego deficitario del olivar: los programas de recorte de riego en olivar. Agricultura 746, 768-776 (in spanish).

Pellenq, J., Boulet, G., 2004. A methodology to test the pertinence of remote-sensing data assimilation into vegetation models for water and energy exchange at the land surface. Agronomie 24, 197-204.

Pereira, L.S., Perrier, A., Allen, R.G., Alves, I., 1999. Evapotranspiration: review of concepts and future trends. J. Irrig. Drain. Eng. 125 (2), 45-51.

Ritchie, J.T., Johnson, B.S., 1990. Soil and plant factors affecting evaporation. In: Stewart, B.A., Nielson, D.R. (Eds.), Irrigation of Agricultural Crops-Agronomy Monograph No. 30. ASACSSASSSA, Madison, WI, pp. 363-390.

Rouse J.W., Haas, R.H., Schell, J.A., Deering, D.W., Harlan, J.C., 1974. Monitoring the vernal advancement and retrogradation of natural vegetation. NASA/GSFC, Type III, Final report, Greenbelt MD, pp. 1-371.

Santanello, J.A., Friedl, M.A., 2003. Diurnal covariation in soil heat flux and net radiation. J. Appl. Meteorol. 42, 851-862.

Schotanus, P., Nieuwstadt, F., De Bruin, H.A.R., 1983.

Temperature measurement with a sonic anemometer and its application to heat and moisture fluxes. Bound.-Layer Meteorol. 26, 81-93.

Schuurmans, J.M., Troch, P.A., Veldhuizen, A.A., Bastiaanssen, M.W.G., Bierkens, M.F.P., 2003. Assimilation of remotely sensed latent heat flux in a distributed hydrological model. Adv. Water Resour. 26, 151-159.

Shuttleworth, W.J., Gurney, R.J., 1990. The theoretical relationship between foliage temperature and canopy resistance in sparse crops. Quart. J. R. Meteorol. Soc. 116, 497-519.

Sugita, M., Brutsaert, W., 1991. Daily evaporation over a region from lower boundary layer profiles. Water Resour. Res. 27, 747-752.
Testi, L., Villalobos, F.J., Orgaz, F., 2004. Evapotranspiration of a young irrigated olive orchard in southern Spain. Agric. For. Meteorol. 121, 1-18.

Twine, T.E., Kustas, W.P., Norman, J.M., Cook, D.R., Houser, P.R., Meyers, T.P., Prueger, J.H., Starks, P.J., Wesely, M.L., 2000. Correcting eddy-covariance flux underestimates over a grassland. Agric. Forest Meteorol. 103 (3), 279-300.

Van Genutchen, M.T., 1980. A closed-form equation for predicting the hydraulic conductivity of unsaturated soils. En Soil Sci. Soc. Am. J. 44, 892-898.

Verhoef, W., Bach, H., 2003. Remote sensing data assimilation using coupled radiative transfer models. Phys. Chem. Earth A/B/C 28 (1-3), 3-13.

Villalobos, F.J., Orgaz, F., Testi, L., Fereres, E., 2000. Measurements and modeling of evapotranspiration of olive (Olea europaea L.) orchards. Eur. J. Agron. 13, 155-163.

Webb, E.K., Pearman, G.I., Leuning, R., 1980. Correction of flux measurements for density effects due to heat and water vapor transfer. Quart. J. R. Meteor. Soc. 106, 85-100.

Wilczak, J., Oncley, S., Stage, S.A., 2001. Sonic anemometer tilt correction algorithms. Bound.-Layer Meteor. 99, 127-150.

Williams, D.G., Cable, W., Hultine, K., Hoedjes, J.C.B., Yepez, E.A., Simonneaux, V., Er-Raki, S., Boulet, G., de Bruin, H.A.R., Chehbouni, A., Hartogensis, O.K., Timouk, F., 2004. Evapotranspiration components determined by stable isotope, sap flow and eddy covariance techniques. Agric. For. Meteorol. 125, 241-258.

Williams, L.E., Ayars, J.E., 2005. Grapevine water use and the crop coefficient are linear functions of the shaded area measured beneath the canopy. Agric. For. Meteorol. 132, 201-211.

Wosten, J.H.M., 1997. Pedotransfer functions to evaluate soil quality. In: Gregorich, E.G., Carter, M.R. (Eds.), Soil Quality for Crop Production and Ecosystem Health. Developments in Soils Science, vol. 25. Elsevier, Amsterdam, pp. 221-245.

Wosten, J.H.M., Lilly, A., Nemes, A., Le Bas, C., 1999. Development and use of a database of hydraulic properties of European soils. Geoderma 90, 169-189.

Zhang, L., Lemeur, R., 1995. Evaluation of daily evapotranspiration estimates from instantaneous measurements. Agric. For. Meteorol 74, 139-154. 